\title{
CHST3-related skeletal dysplasia
}

INSERM

\section{Source}

INSERM. (1999). Orphanet: an online rare disease and orphan drug data base. CHST3related skeletal dysplasia. ORPHA:263463

CHST 3-related skeletal dysplasia is a very rare bone disorder characterized clinically by short stature of prenatal onset; dislocation of the knees, hips or elbows; club feet; limitation of range of motion of large joints; progressive kyphosis; and occasional scoliosis. In a few patients, minor heart valve dysplasia has also been described. Intellect, vision and hearing are normal. 